\title{
TRIP700 ACÉL ELLENÁLLÁS-PONTHEGESZTÉSE
}

\section{RESISTANCE SPOT WELDING OF TRIP700 STEEL}

\author{
Kozma Bálint ${ }^{1}$, Dobránszky János ${ }^{2}$ \\ ${ }^{I}$ Gépészmérnök hallgató, BME Gépészmérnöki Kar, Anyagtudomány és Technológia \\ Tanszék, 1111 Budapest, Müegyetem rakpart 3. Magyarország; + 36 20-500-4937, \\ balint.kozma@outlook.com \\ ${ }^{2}$ Tudományos fömunkatárs, MTA-BME Kompozittechnológiai Kutatócsoport \\ 1111 Budapest, Müegyetem rakpart 3. Magyarország; telefon: +36 1-463-1934, \\ dobranszky.janos@eik.bme.hu
}

\begin{abstract}
Increasing demand for advanced steels with outstanding mechanical properties appeared in the modern vehicle manufacturing. These materials are used mainly in the automotive industry as parts for high loads (i.e. car body, chassis). The application of multi-phase steels, i.e. TRIP steels is an obvious solution in the automotive industry.

Car body elements assembled of several pieces by various technological solutions (spot welding, bonding). One of the most widely used methods is the resistance spot welding. By this method the welded joint prepared in seconds that is significant in the automotive mass production. During the welding of TRIP steels cracks could appears around the nugget.
\end{abstract}

Keywords: resistance spot welding, TRIP steel, high strength steel, design of experiments.

\section{Összefoglalás}

A jármügyártásban fokozott igény mutatkozik olyan acélok iránt, melyek nagy szilárdságuk mellett jól alakíthatók. Ezek a nagy terhelésnek kitett helyeken kerülnek alkalmazásra: a karosszériaelemek (Aés B-oszlop) és az alvázszerkezet egyes részeiként. A jármügyártás számára kézenfekvő megoldás alkalmazni a többfázisú acélokat, melyek nagy szilárdságúak és képlékenyen jól alakíthatók; pl. a TRIPacélokat). A karosszériaelemeket akár több darabból kötik össze, alkalmazva a ponthegesztés különféle változatait, a ragasztást vagy ezek kombinációját. Az egyik legelterjedtebb ilyen kötési eljárás az ellenállás-ponthegesztés. Ezen eljárással a kötést másodpercek alatt készíthetjük el, aminek kiemelkedö a jelentősége a jármüipari tömeggyártásban. Az hegesztés során azonban a TRIP-acélokra jellemző, hogy a varrat határvonala mentén és a varratban kristályosodási repedések jelennek meg.

Kulcsszavak: ellenállás-ponthegesztés, TRIP-acél, kísérlettervezés.

\section{Bevezetés, célkitűzés}

A TRIP-acélok szövetszerkezete összetett: ferrit mátrixban bénit, martenzit és maradék ausztenit található. Képlékenyalakítás hatására az ausztenit részben vagy teljesen martenzitté alakul, az anyag jelentős kemé- nyedésnövekedést mutat. Az autóiparban az ellenállás-ponthegesztést, a ragasztást vagy ezek kombinációját és a lézersugaras hegesztést alkalmazva egyesítik az alkatrészeket. Ma is a legelterjedtebb megoldás az ellenállás-ponthegesztés. A TRIP-acélok varratának határvonala mentén és a varratban 
kristályosodási repedések jelenhetnek meg. Ezt a levegő nitrogénjével hozzák összefüggésbe. Célunk a TRIP-acélok hegeszthetőségi jellemzőinek elemzése volt.

\section{Előzetes vizsgálatok}

A kísérlethez $0,8 \mathrm{~mm}$ vastag TRIP700 típusú acélt használtunk, horganybevonata $\sim 10 \mu \mathrm{m}$ vastagságú volt. Szakítóvizsgálattal meghatároztuk a hengerlés miatt kialakult anizotrópiáját. A vizsgálat eredményéből számítható a Lankford-szám: a kereszt- és hosszirányú alakváltozás aránya (1. táblázat). Ha a Lankford-szám 1-től eltérő, az anyag mechanikai tulajdonságai a terhelésnek a hengerlési iránnyal bezárt szögétöl függő mennyiségek [2].

1. táblázat - A Lankford-számok az ismeretlen hengerlési irányú kísérleti anyagon

\begin{tabular}{|c|c|}
\hline $\mathrm{R}_{0}$ & 1,276 \\
\hline $\mathrm{R}_{45}$ & 1,761 \\
\hline $\mathrm{R}_{90}$ & 1,902 \\
\hline
\end{tabular}

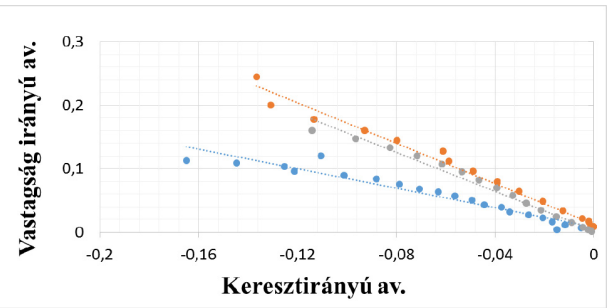

\section{1. ábra-A Keeler-Goodwin-diagram}

Az alakváltozásából meghatározható a Keeler-Goodwin-diagram. A diagram egy általános lemez anizotrópiája esetében azt mutatja, hogy a 0 és 90 fokos irányhoz tartozó Lankford-számok közel azonosak, a 45 fokosé pedig eltérő értéket vesz fel [2]. Esetünkben a mért értékek között ez a kapcsolat nem áll fenn, feltehetően az általunk definiált 0 és 90 fokot irányok eltérnek a lemez tényleges hossz és keresztirányú tengelyeitől. Az általunk meghatározott diagramon jól látható, hogy 45 és 90 fokos irány- hoz tartozó meredekségek közel azonosak, ettől eltérő a 0 fokos.

$\mathrm{Az}$ anizotrópiavizsgálat következtetése tehát az, hogy a rendelkezésre álló próbatestek, melyek hossztengelye egymásra merőleges, egymással nem kombinálhatók.

\section{Kísérleti hegesztések}

\subsection{Kísérlettervezés}

A helyes kísérletterv megléte, nagy jelentőségü. Ebből következik, hogy célunk a lehető legkisebb számú kísérletből a számunkra releváns információk maximumának kinyerése [3].

Statisztikai kísérlettervezés során olyan optimalizálást végzünk, melynél az objektum mechanizmusa nem teljesen ismert. Mindig felhasználjuk a korábban elvégett kísérletek eredményeit, a rendelkezésre álló ismereteket az adott jelenségről [3].

Többfaktoros kísérlet esetén faktoroknak a független változókat nevezik, ezek beállítandó értékét faktorszintnek nevezik, a célfüggvény a függő változó vagy több függő változó esetén azok kombinációja. Az optimalizáló kísérlettervezés során nem célunk az objektum tökéletes megismerése, az összefüggések feltárása, csupán egyszerü lineáris és másodfokú függvények alkalmazásával az optimális müködési tartományt jellemző független változó értékét keressük, a kiértékelés során pedig matematikai öszszefüggéseket alkalmazunk.

A $2 p$ típusú tervek $p$ faktort tartalmaznak, melyekből mindet két szinten vizsgálják, így ha minden beállításnál egy kísérletet végzünk, a kísérleti terv $\mathrm{N}=2 \mathrm{p}$ pontot tartalmaz. [3]

Az itt tárgyalt kísérletek esetében három faktort jelöltünk ki: ezek a hegesztési áramerősség (I), a hegesztési idő (t), illetőleg az elektródák által kifejtett nyomóerő (F). Célunk, hogy az adott alapanyag esetében meghatározzuk a legnagyobb kötésszilárdsághoz tartozó technológiai tényezők értékét. 


\subsection{A berendezés mérése}

A kísérletekhez használt ellenállásponthegesztö berendezésen a hegesztési tényezők beállítására 0 és 99 közötti skálák szolgálnak. Az áramerősség-skálát méréssel határoztuk, a 2. ábra szemlélteti.

A nyomóerő meghatározásához ismerni kell, hogy a berendezés adott karhosszán, adott gáznyomás mellett mekkora nyomóerőt fejt ki; ezt mutatja a 3. ábra.

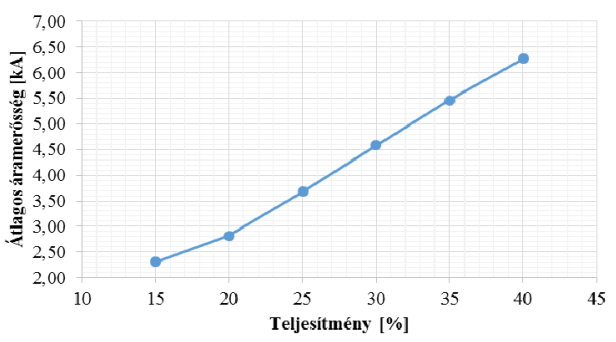

2. ábra - Az áramerösség-teljesitmény diagram

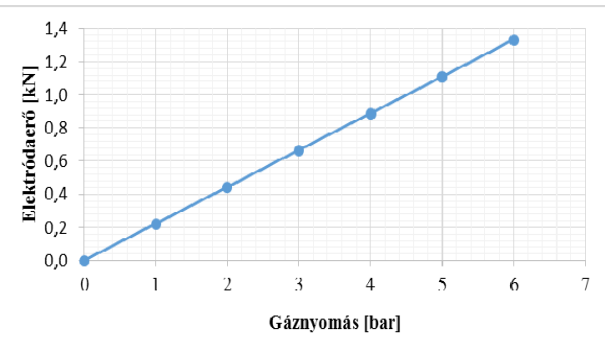

3. ábra - Elektródaerö-pneumatika nyomás

A harmadik faktort, a hegesztési időt, a berendezésen állíthatjuk be.

\subsection{A tervezési mátrix}

Teszthegesztéseket végeztünk, melyekkel megállapítható az egyes faktorokhoz tartozó alsó- és felső szint. A várható legnagyobb hatású faktornak az áramerősséget vettük, a nyomóerő (4 bar) és a hegesztési idő pedig konstans (10 periódus). Célunk meghatározni azt a legkisebb/legnagyobb áramerősség értéket, melynél a kötés éppen elégséges, illetőleg a sorjakifröccsenés eröteljessé válik. A meghatározott faktorszintek a következők:
2. táblázat-Faktorszintek

\begin{tabular}{|l|c|c|}
\hline & Alsó & Felső \\
\hline Áramerősség, I (kA) & 2,5 & 6,5 \\
\hline Hegesztési idő, t (periódus) & 5 & 15 \\
\hline Elektródanyomás, p (bar) & 2 & 6 \\
\hline
\end{tabular}

A tervezési mátrix elemeit, mely az optimumkeresési kísérleti beállítások értékeit tartalmazza, az Unscrambler X programmal határoztuk meg. Összesen 17 kísérleti hegesztést jelöltünk ki. A feladat e kötések elkészítése, vizsgálata és kiértékelése volt.

\subsection{A hegesztett kötések vizsgálata}

A kísérleti kötéseket nyíró-szakító vizsgálatnak vetettük alá, és meghatároztuk a tönkremenetelhez (kigombolódásához) tartozó maximális erőt, amelyet a keresztmetszetre vonatkoztatva meghatároztuk a maximális (nyíró-szakító) kötésszilárdságot (1222 MPa).

Az elemzést lineáris modell illesztésével, majd az első- és másodrendü kölcsönhatásokat elemezésével végeztük. Első körben az illesztés megfelelőnek bizonyult, ám a hatások közül egyik sem volt szignifikáns, így azok elhanyagolhatók minősíthetők. Az amit ilyen esetben tehetünk az, hogy a legnagyobb p-értékhez tartozó faktorokat kivesszük a következő elemzésből.

A második közelítés során a regressziós görbe illesztése ugyan romlott, mivel egyszerübb térbeli alakzattal közelítettük a regressziós függvényt, de egyes hatások szignifikanciája megfelelő lett.

\section{3. táblázat - A független változók szignifikanciája}

\begin{tabular}{|l|c|}
\hline Technológiai tényezö, $\beta$ & Szignifikancia \\
\hline Áramerösség (A) & + \\
\hline Hegesztés ideje (B) & +++ \\
\hline Elektródanyomás (C) & NS \\
\hline $\mathrm{A}^{*} \mathrm{~B}$ & $\mathrm{NS}$ \\
\hline $\mathrm{A}^{*} \mathrm{~A}$ & $?$ \\
\hline $\mathrm{B}^{*} \mathrm{~B}$ & $\mathrm{NS}$ \\
\hline
\end{tabular}




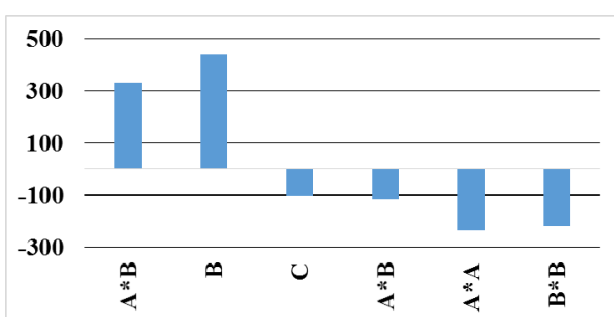

4. ábra - A hatások ábrázolása

A kötésszilárdság adatokra illesztett, ún. válaszfelületeket az 5. ábra mutatja:
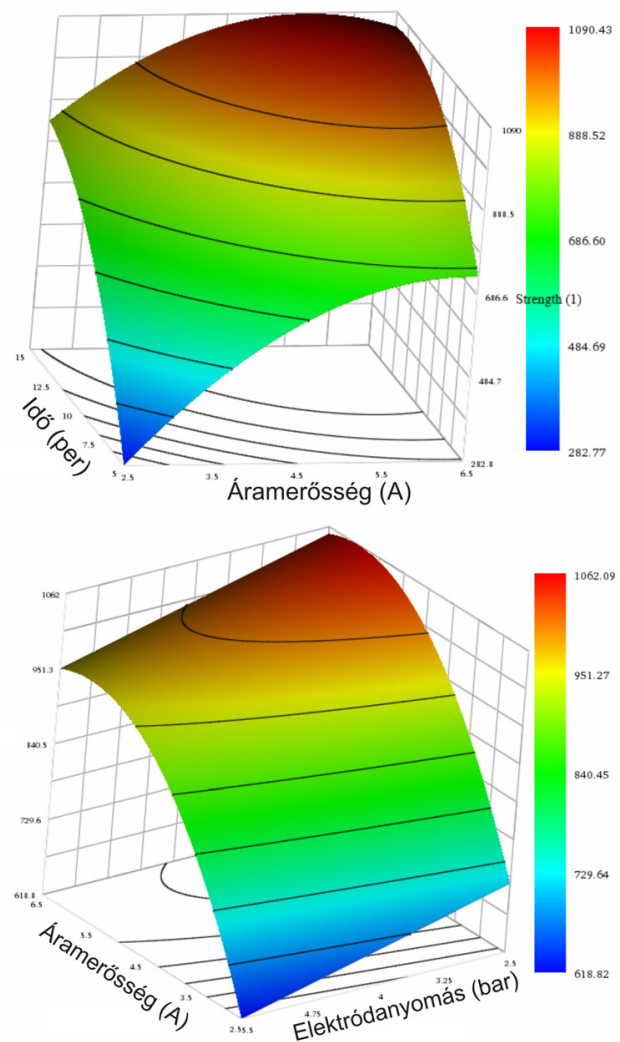

5. ábra - Kötésszilárdság az idő és áram (fent), illetve az áram és a nyomás (lent) függvényében

Az ábrákon látható, hogy mindkét görbének szélsőértéke van valahol, azonban ezek a vizsgált térrészből kilógnak. Ez arra enged következtetni, hogy a vizsgált faktorok tartományai túl szük intervallumban vettük fel.
Így az optimumot csak közelítő értékekkel tudjuk megadni, melyek:
Áramerösség
$=5,6 \mathrm{kA}$
Hegesztési idö
$=15 \mathrm{per}$
Elektródanyomás
$=0,56 \mathrm{kN}$

Szemrevételezést és folyadékbehatolásos vizsgálatot követően megállapítottuk, hogy a kötések felületén kristályosodási repedések találhatók, tehát a fennálló kötési hibákat első ízben nem sikerült megelőzni.

Ehhez további, a „klasszikus” kísérletezésnek megfelelő módszerrel folytattuk a vizsgálatot, mely során a hegesztést követően hőkezelési ciklusnak vetettük alá a próbadarabokat, alapjait pedig a közel optimális paraméterek adták.

Eredményként a felületre kifutó összes repedéshosszt mintegy ötödére csökkentettük (gyakorlatilag elhanyagolható kiterjedésre), esetenként teljesen eltüntek.

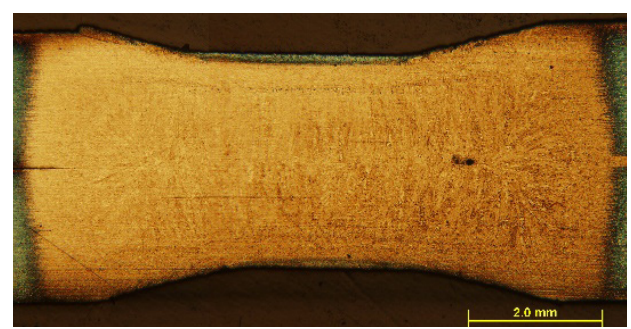

6. ábra - Egy minta keresztcsiszolata

\section{Szakirodalmi hivatkozások}

[1] Szunyogh L: Hegesztés és rokon technológiák-Kézikönyv. GTE Budapest, 2007.

[2] Ziaja Gy: Alakitástechnika. Kézirat, 2004.

[3] Kemény S, Deák A: Kisérletek tervezése és értékelése. Müszaki Könyvkiadó, Budapest, 2002,

[4] The Unscrambler X Help

[5] Chao YJ: Ultimate strength and failure mechanism of resistance spot weld ... J. Eng. Mater. Technol. 125 (2003:2) 125132.

[6] MSZ EN ISO 14272:2002 és MSZ EN ISO 14273:2002 szabványok,

[7] Gáti J: Hegesztési zsebkönyv. 2003

[8] Komócsin M: Anyagok hegeszthetősége, www.tankonyvtar.hu/hu/tartalom/tamop412A/ 